\title{
Nitrate ruins: the photography of mining in the Atacama Desert, Chile
} Louise Purbrick, University of Brighton

\section{Ruins}

The sites of many former nitrate oficinas, the abandoned mines of the Atacama Desert, are visible from inside a car travelling along the Pan Americana. The long views of cloudless sky and bare land, both empty expanses, are irregularly punctuated by long, low, flat, ochre mountains. The sand road that leads to the Oficina Alianza is indicated by a battered metal signpost (Figure 1). The flat mountains frame the former nitrate oficina site. Initially they appear as natural features gently sloping down to form a valley within which an industrial town once nestled. But these mountains grew up around the oficina as cart load upon cart load of the residue of nitrate processing, ripio, was tipped out, dumped to each side of the processing plant. The mountains are slag heaps. They dominate nitrate oficina sites, enclosing the view of fragmentary industrial structures, half clad buildings and fallen walls.

Industrial ruins are a favoured subject of contemporary photography (Strangleman, 2013). Their emptiness appeals to the uncanny effects of analogue film; its exposure captures a moment of time as a past that is unreachable except as loss. The photograph is a trace of a trace. Oficina Alianza, however, was meticulously documented when it was fully operational and densely populated. A photographic album entitled Oficina Alianza and Port of lquique $1899^{1}$ illustrates the industrial development of nitrate mining in Chile. This album, a record of a working nitrate oficina, and its remains, an abandoned industrial ruin, are examined in this essay. It reflects upon how the histories of nitrate mining in Chile from the late

\footnotetext{
${ }^{1}$ Oficina Alianza and Port of lquique 1889 is listed as Album 12 by Fondo Fotográfico Fundación, Museo Universidad de Navarra, Pamplona. The album featured in Xavier Ribas's exhibition, Nitrate, MACBA, 2014 (http://www.macba.cat/en/expo-ribas-nitrate). I would like to acknowledge the support from Arts and Humanities Research Council for the research that contributed to the exhibition and this article.
} 
nineteenth to the early twentieth century are held in both the photography and the landscape of the Atacama. Nitrate mining in Chile is a history of loss and its ruins lend themselves to an account of the ruin as a historical form. Loss in the remote mining satellites of a metropolitan industrial economy is ever present rather than buried in the past. My account of the fallen walls of Alianza, following in the well-worn footsteps of Walter Benjamin, considers the allegorical properties of ruins alongside the analogic ones of photographs. One ruin is not just like another; one bundle photographs is not only analogous; both are artefacts of particular past and present. Thus, this essay attends to the historical moment and specific forms of Alianza: a modern industrial ruin and its photographic documents.

Nitrate was extensively and intensively mined in the Antofagasta and Tarapacá regions from the late nineteenth to the early twentieth century. The industry was driven by British capital and capitalists (Monteón, 1975). Industrial efficiencies of the export trade in nitrate, and the architecture of oficinas, was built upon the Shanks system, an adaptation by the English engineer James Shanks of the French Leblanc process of manufacturing soda (Haber, 1958: 252-254). Shanks devised an arrangement of large tanks that allowed continuous gravitational cycles of lixiviation, the separation of soluble and insoluble chemicals, which was adapted by James Humberstone for nitrate production. Rocks called caliche were exploded from the desert surface, crushed, dissolved and heated to separate nitrate from ripio. The Atacama held only caliche in abundance and little more: everything else was supplied. Materials for the construction of the entire oficina were imported from Britain: boilers, tanks, tubes, pumps, machine-tools, steam engines, railways and rolling stock, coal and corrugated iron were sent over transnational trade routes, from Liverpool or London via Australian ports, to Iquique, Chile. Labouring men, Chilean, Bolivian and Peruvian, were brought and bound through an enganche system to live in the nitrate oficinas (Monteón, 1979). Imported materials were continually supplied to sustain working lives in the desert, but at a profit. Nitrate workers, promised three 
pesos a day were paid in fichas, the company tokens that were only currency accepted for overpriced goods in the company stores.

\section{Correspondences: photographs and ruins}

At Alianza, the ruins of nitrate industry in the landscape corresponds to the series of images bound together in the album of photographs, Oficina Alianza and Port of Iquique 1889. The correspondence works in a number of ways. There is a resemblance between present and past views of the same place, a similarity between landscape and photographic records. Both are traces but of a different materiality, impressions of the same structures upon different forms: the desert floor or prepared paper. The visual and material parallels between these records permit another kind correspondence: an exchange across time, a tracking back and forth between the past and present of the same space.

The photographic album contains over 90 photographs of the nitrate industry and a piece of correspondence. The letter, dated 18 July 1900 , from nitrate company manager Mr Smail asked the head of the merchant house for whom he worked, Henry Hucks Gibbs, of Antony Gibbs and Sons, to accept the album 'as a souvenir as our last but I hope not least among nitrate oficinas'. He did. 'I am much obliged to you for the excellent photography of the Alianza,' Henry Hucks Gibbs replied. It was a 'handsome volume', he remarked with a compliment: 'If the business itself produces a corresponding handsome result, it will be in great measure be down to your zeal and ability, which are fully appreciated by my partners as well as by me.' Thus the album, Oficina Alianza and Port of lquique 1899, is acknowledged as an analogy of the nitrate trade. For its recipient, Gibbs, the correspondence between photography and place is also one between photography and profit.

The photographs are arranged two on a page throughout the album until the final pages, which present the Pacific ports: these unfold as panoramas. The album is an industrial topography; it documents the processes of mining, refining, 
transporting nitrate across a changing landscape. It combines the conventions of colonial and industrial photography: the empty land and indigenous subject, the dynamism of machinery and the drama of material transformation. There is also a set piece industrial image of labouring men, their strength held still for the camera (Figure 2).

The first image, the number 1 scratched onto its photographic plate, is entitled 'General View of Grounds and Works' and prepares the viewer for the following ninety; it sets the scene, indicates almost everything that is in store (Figure 3). An empty sky spreads over a flat desert; the details of its surface captured on the large plates of the camera. Clumps of rocks on an uneven ground are depicted by shadows. The tracks of the railway line on the left side of the image have dark sharp shadows that form long straight lines of perspective that propel the viewer to a building then a wall. The wall leads to a line of low buildings that cut across the horizon where desert fades into the sky, providing another line of sight that draws attention across the image towards a distant factory building. The railway tracks generate a geometrical order; the lines square off the desert to shows a worked and controlled landscape. Within a measured boundary, the uneven surface of the desert becomes a nitrate field, one of the 'Grounds' of industry, to use a word from the image's written title. Tracks, walls and buildings are, furthermore, lines of movement, visual and geographical trajectories. Their destination, on the far right of the horizon is the oficina. Its smoking chimneys, an index of industrialisation.

The opening image promises activity, but little happens at first. The second image, below the first and on the same page, is entitled 'Virgin Nitrate Grounds': it is almost featureless, a photograph of nothing, no event, no action (Figure 4). It consists of two blocks of colour: a pale earth and paler sky. It displays the desert as vast empty expanse, an uninhabited land, waiting for something to happen. The human figure is scaled small against the desert to demonstrate its emptiness and readiness. This view is presented as the moment before the oficina opened; there 
are no smoking chimneys, no signs of industry. The photographer has re-framed geography as history; he has simply pointed his camera away from the Oficina Alianza, the fully operational oficina. He has produced another view of the desert as past of the oficina; thus his sequencing of photographs becomes an account not only of the operation of Alianza but also the industrialisation of the Atacama Desert.

Over the next ten images, things start to happen; the photographs contain activity: men balanced on the desert's rocky surface or bent over levering out rocks in opened trenches, mules ready to pull carts of caliche. Each image records an event in the surface mining of nitrate, including an explosion, 'Blasting of Test Hole', but they remain desert views: expansive ochre fields under a large empty skies (Figures 5 and 6). The desert landscape dominates until the arrival of technology. Or, to put this less dramatically, the view changes as the work of the oficina becomes the object of the camera work, the subject of the image. The tenth image, 'Loading Caliches into Railway Trucks, presents a railway engine; it is at halt, steam spurting from its pipe (Figure 7). The chain of trucks pulled behind it spans almost the entire horizontal plane of the image. Human figures, calicheros, form a background for the railway engine and trucks. At first glance, they appear without prior arrangement; they stand between the carts or on their horses, occupying the positions necessary to move caliche, via a railway, into the oficina. On closer inspection, however, all are patiently presenting themselves and their stocks of caliche, a picture of industrial plenty and worker passivity, to the photographer whose position below left (bottom right from the viewer's perspective) can be determined by follow the gazes of the calicheros. Had they been waiting for his signal to release the back panel of the cart and raise it so he could capture the fast falling high stack of caliche into the railway trucks? Moving materials are registered as blurred shapes on the chemically coated glass plate; they cannot be stilled or staged like human subjects for the necessary exposure times. These clouds that indicate a material transformation has taken 
place, avalanches of nitrate in its changing forms, is one of the dramas of the documentation of nitrate mining and features several times within the album.

'Loading Caliche into Railway Trucks' and the nine images that preceded it are part of a sequence of forty photographs that trace the mining and manufacture of nitrate. It is an account of the stages of industrial production from raw material to waste matter or export commodity and a narrative of material transformation from a mineral deposit in a desert rock to a chemical, bagged and ready for transport (Figure 8). Each material transformations recorded on the camera's plate, the particular moment when surface of the desert was exploded, when caliche was split apart, prised away, tipped into trucks then crushed, dissolved, separated, refined into sodium nitrate to leave its residue, represents the process of industrialisation itself. The photographic image of particular material transformations appears as a stage of general geographical and historical improvement; every small act of appropriation of the materials of a dry desert an analogy of industrial progress.

Once the caliche has been transported to the oficina the photographic focus changes; the camera is closer to the action. Machinery, materials and men are the subjects of this sequence. In one portrait image, simply labelled 'Crushers', the large panels of metal bolted together and covered in salty white residues extend from the top right to the bottom centre of the image forming a ravine with the vertical wall on the left hand side (Figure 9). An evenly paced row of huge wheels fill the ravine, extending backwards in pleasing lines of perspective to a window of light. A nitrate worker, the folds of fabric in his loosely bound clothing contrasting with geometry of machinery, balances between the wheels, leaning gently and gracefully over a triangular shoot. He and the figures that lie behind him appear as emplacements in a mechanical system. In another balanced pictorial composition, 'Emptying Bateas', an industrial platform extends until a strip of blank sky (Figure 10). Rectangular metal tanks packed high with mounds of nitrate fill over half the picture frame; their bolted metal sides rising either side of parallel tracks provide more lines of perspective that 
meet at cart into which workers shovel refined, white nitrate. The symmetry is repeated in the arrangement of workers around the cart: four on each side in the act of shovelling, two with shovels full of nitrate ready to be tipped. Again, materials in motion are caught by the camera or, rather, convened for the camera. The industrial activity of shovelling crystallized nitrate ready to be dried is demonstrated by positions held by nitrate workers; the slackened shoulders of enforced stillness indicate a pose kept for a little too long, patience tried by photography. Nevertheless all workers are shown embedded in machinery and materials, playing their part in Shanks system. This sequence of the Oficina Alianza and Port of Iquique 1899 presents order and activity, the ideal character of industrial production. This sequence is the centrepiece of the album and is a photographic performance of industrial capital; machinery and labour is arranged together, operating for the recipient of the album, the most senior partner in Antony Gibbs and Sons, as an analogy of profit.

When the nitrate is loaded onto the train to leave desert (Figure 11), the sequence ends and another begins. A tour of the nitrate works and nitrate town in twenty photographs opens with an interior of the 'General Stores' (Figure 12). This sequence is an interlude. It depicts the working and social life of an industrial town: workshops, offices, market scenes, houses (Figure 13). The provisioning routines of nitrate workers and their families are pictured several times. Here the Oficina Alianza and Port of lquique 1899 album reproduces the anthropological curiosity directed at remote village cultures or the quarters of industrial poor. The industrial enclave of the oficina could be considered either. However, the tour of the town is also a continuing account of activity recorded in the rest of the album; the oficina is bustling with the material exchanges of modern life: buying goods. The 'General Stores' image not only opens the sequence, its display of industrial objects illustrates that nitrate mining 
is substantial affair, a thriving business. ${ }^{2}$ The repetition of forms, in this image, and throughout the album, is reassuring: another indication of industrial productivity. ${ }^{3}$ The pictures of accumulation of things viewed in the London offices of a merchant bank are signs that their investment is working.

The narrative of the album is reaching its conclusion. A photograph of the arrival of A train pulling sacks of nitrate arriving at the port of lquique opens a sequence of ten photographs that tracks the final stages of nitrate's journey as it transferred from vehicle to vehicle, stack to stack, from train to warehouse, warehouse to dock, boats to ships (Figure 14). All offer evidence of the quantity of nitrate, the scale of export trade, the movement of materials. The effect of the images is cumulative: the material transformation and geographical passage of nitrate ends in a drama of plenty. Bags upon bags of stuff, an over abundance of materials, was an established form of exhibiting the concluding achievement of industrial development. The final sequence of the Oficina Alianza and Port of lquique 1899 is an epilogue to all this. It comprises a long unfolding panorama of the Port of lquique as well as two shorter ones and two 'General Views' of other Pacific ports. These departing shots are taken from elevated positions that re-establish the distance between photographer and landscape; they return to the topographical vision with which the album opened (Figure 15). Its narrative of material transformation and industrial production is thus a record of occupation of a space between the open desert and the wide sea. Fields of nitrate have been blown apart, built upon, filled with industrial structures and industrial subjects; the photographs of Oficina Alianza and Port of lquique 1899 are documents of industrial colonisation.

\footnotetext{
2 The inflated prices paid in fichas for goods supplied to nitrate oficinas are not visible in the photographic record although these tokens were plentiful enough to be preserved and are now collector's items (Espinosa, n.d).

${ }^{3}$ I would like to thank Photographic History Centre seminar, (De Montford University, 11 November 2014) for the discussion of reassurance and industrial photography.
} 
'[I]nstitutionalised industrial photography' is, stated Alan Sekula, 'characteristic of the epoch of monopoly capitalism' (Sekula, 1986). The Oficina Alianza and Port of lquique 1899 is a standard form applied to nitrate mining in northern Chile; the images of lines of geometry cut into a desert topography by machinery, those of labour arranged in an ordered landscape and of the transformation of rough hewn earthly materials into bagged commodities are records the reach of capital to the remote spaces of an inhospitable world (Clark and Foster, 2009). They are 'general views,' to borrow the title of album's first image, of capital itself, a pictorial analogue. They are also specific representations of Antony Gibbs and Sons' business interest in the Atacama Desert and documents of their part in a nitrate mining monopoly.

\section{Monopoly capital and nitrate mining}

The material forms of nitrate mining documented in Oficina Alianza and Port of Iquique 1899 and now only visible as lines in the desert or fallen walls, were shaped by global trade and European industrialisation, monopolistic merchant houses and capitalist speculators. They were founded upon the prehistoric rock formations of the Atacama Desert, erected close to concentrations of caliche, the ores containing nitrate. The site was set in geology but everything was determined by capital. Indeed, it was the development of industrial monopoly capitalism that brought oficinas into being; they opened and closed according to cycles of overproduction, boom and slump, typical of this economic system. Oficina Alianza, of strategic importance to Antony Gibbs and Sons in an attempt to protect their economic ascendancy in Atacama against the incursions of another British nitrate capitalist and speculator, John Thomas North, illustrates how the forces and relationships of capital shaped the spaces of the pampas.

The nitrate fields of Alianza were unworked over much of the period of the trade's height, the last two decades of the nineteenth century. The Alianza Company, 
an alliance, as the Spanish name suggests, of Chilean and English speculators in which Antony Gibbs and Sons had the controlling interest, went into operation in the final years of the 1890s. It was the 'last' of the Antony Gibbs and Sons oficinas as Mr Smail's correspondence of July 181900 notes. Its late opening was not, as might be expected, related to the high but fluctuating demand for nitrate as a fertilizer that increased crop yields to feed expanding European urban populations whenever farmers could afford the supplement to their growing costs. The existence and operation of Alianza, from the first test hole exploded in the fields of caliche to the last shovel of ripio tipped onto a slag heaps, was dependent upon, even determined by, the competitive relationships of monopoly capitalism.

Monopoly was the character of trade in nitrate. Following Chile's victory over neighbours Peru and Bolivia in the 1879-1883 War of the Pacific, which German historians call the Saltpeterkrieg (Miller and Greenhill, 2006: 229), the natural monopoly of sodium nitrate of the Atacama was intensively exploited. Capital, often loaned and controlled by British merchants and speculators, unearthed and encroached upon a desert (Monteón, 1975). One nitrate company would own several nitrate fields, nitrate oficinas and a warehouse in lquique or Pisagua where sacks of nitrate were stored awaiting export to Liverpool and Europe. Upon export, the Chilean government taxed each quintal of nitrate, an amount approximate to a hundred weight. High production of nitrate delivering high volumes of exports was in the Chilean national interest: more nitrate accrued more state revenue. But high exports supplying large amounts of nitrate to farmers and chemists, agricultural or chemical industries, lowered prices in European markets. It was in the interest of British (and other foreign) nitrate companies to restrict production, reduce exports and raise prices. Nitrate speculators sought to avoid falling nitrate prices that affected the value of shares in nitrate companies. To do so they formed nitrate mining monopolies. Thus, over-production was the problem of nitrate capitalists (as it is for the capitalism of mining more generally) but the source of income for Chile: market 
and nation were fatally opposed. Successive combinations of competing nitrate companies, that is, monopolies, were established to regulate production and ensure the stable or even inflated shares; there were five combinations between 1884 and 1909 (Brown, 1963); it is the second of these that is most significant in the history of Alianza.

The railway companies that transported nitrate from desert to the sea were one of the most powerful foreign monopolies: they were 'key' to profits in the nitrate trade (Blakemore, 1974:45-60). Railway companies charged nitrate companies for transportation. They over-charged. As the only means of transporting of nitrate across the Atacama Desert, since cart and mule could not possibly carry industrial quantities over such distance, very high tariffs per quintal of nitrate were imposed. One firm, the Nitrate Railway Company held a monopoly of the lines of Tarapacá, based concessions granted to Ramón Montero and Brothers by Peruvian government before it lost control of territory in War of the Pacific (Brown, 1958). In 1882, a year before Tarapacá's annexation by Chile, the Montero Brothers registered their firm in London. Five years later, in 1887, the bombastic British nitrate speculator John Thomas North bought 7,000 shares and in the following year became company director (Edmundson, 2011). Competitive British interests directed nitrate trafficking. John Thomas North's railway monopoly challenged the commercial ascendancy of Antony Gibbs and Sons in Chile and directly affected the development of Oficina Alianza. In 1890, Herbert Gibbs complained to Foreign Office that 'the monopoly of the Nitrate Railways was weighing unmercifully upon British capital invested in the Nitrate works' (Blakemore, 1974:132; Brown, 1958: 476) He, the son of Henry Hucks, made a case that the British government representatives in Chile should withdraw support for North's Nitrate Railway Company currently opposing in Chilean courts 'infractions' of its monopoly by a new railway line built by another British company, Campbell Outram, that would connect the nitrate fields of Agua Santa to the port of Caleta Buena. The Foreign Office seemed uncertain who to back, Gibbs or North, 
indicative of some reluctance by the British state to arbitrate between the interests of capitalists abroad. Whilst Gibbs' lobbying may not have immediately effective, it was an aspect of political brinkmanship in the protection industrial profits also played out in Chile. Through their man in Valparaíso, Mr. B.A. Miller, Gibbs also bargained inconclusively with Chilean President José Balmaceda about a railway line and port to serve Alianza (Blakemore, 1974: 145). An economist nationalist, Balmaceda supported the Agua Santa line because it undermined a foreign monopoly and could promise reduced transport tariffs that cost small Chilean nitrate producers dearly. Balmaceda offered to permit Gibbs' construction of a railway line from Alianza to the coast at Chucumata on two conditions: a guaranteed annual minimum of two million quintals of nitrate sent through the new port and a promise not to enter into a combination, a 'Monopol (Blakemore, 1974: 146). Over production in 1889 led to negotiations between nitrate producers then to what would become the second nitrate combination led by 'English companies' with a Permanent Nitrate Committee based in London, established from in March 1891 (Brown, 1963: 234-5). The much quoted warning about future of Tarapacá, 'we ought not to allow this rich and extensive region to be converted simply into a foreign factory', summarises Balmaceda's opposition to British monpolistas (Blakemore, 1974; 150). That the market and the nation were opposed is not entirely accurate. In 1891, the market divided the nation, set Chilean Congress, whose political elites were entangled with European nitrate interests, against a President seeking to moderate and regulate those same interests. Congress revolted and war, fought in the nitrate provinces and over competitive control nitrate trade, lasted until Balmadeca's defeat and suicide in September. The new government continued to oppose the monopolistas and the second combination, which controlled nitrate production and prices from 1891 until 1894 (Brown, 1963: 236-238). Another combination would take its place in 1896 but by 1894 the railway monopoly was over. The completion of the Agua Santa line opened an alternative nitrate export route to lquique, compelling North's Nitrate 
Railway Company to reduce extortionate transport tariffs (Brown, 1958: 479). The conditions for nitrate mining at Alianza were met. The bundle of photographs sent to Gibbs' London office followed. The Oficina Alianza and Port of lquique 1899, a standard institutional industrial photography of the general productivity of capital was also, and more specifically, a portfolio of visual evidence of Gibbs' position in nitrate trade monopoly.

\section{Ruins of the future}

Andrea Jösch argues that these photographs are views of the future. In her essay, 'The photography of an inhospitable territory', she writes: 'The images of nitrate are symbolic cartographies that appropriate an imaginary, in this case something like the recording of 'what is to come' (Jösch, 2014: 45). Industrial photography is always orientated towards the future; its subject is the process of material transformation, environments affected by human and technological intervention. The camera, itself a technological instrument, captures dynamism of technology and, with a mix of chemical treatments, reproduces the view in front as an image of the way ahead. The upheavals of industrialisation, its material transformations, appear as progress. Furthermore, Jösch observes that nineteenth century Chilean photography was directed towards modern subjects and it is these images that contributed to an official national visual record of the 'modern world', she lists, 'in the form of industrial scenes, manual labour, standardised portraits etc' (Jösch, 2014: 44). Thus the photographs of nitrate mining record a future indicated by all industrial photography: the modern business of production, a forward movement of things that gives rise to the optimism of industrial capitalism. But these images of nitrate mining kept safely archived in 'the State's most important archives' reveal an unfulfilled future. As they document early twentieth century industrial plenty and capital accumulation they also indicate the later twentieth century historical trajectory of the depletion of the 
Atacama's mineral wealth, relinquished control over Chilean industrial development, foreign military intervention. A future coup is visible in retrospect.

Mining always produces waste and wastelands. Useful and valuable materials are extracted from the earth to leave the useless and valueless. Lands are emptied of its substances and its spoils are scattered. Mining industries tend to expand rapidly as markets for newly unearthed substances boom. The rushes for future material wealth, hurtles the mine into decline. The faster materials are extracted the quicker the slump and accelerated fall in value to leave only waste. The boom before the slump is the subject of Oficina Alianza and Port of Iquique 1899 album but it is not a simple depiction of a productive past. Turning its pages, looking at and over its sequences of industrial development begins as a retrospective experience but becomes a matter of seeing the future unfold in the images. This is, I suggest, what Jösch means when she claims they can be considered records of 'what is to come.' The material forms of the nitrate industry contain the failure of the future. She also states:

the photographs of the architectural structures of the nitrate plants and the stereotyped portraits of workers and indigenous people can become ruins that foreshadow catastrophe and killing, places of segregation and spaces of capital (Jösch, 2014: 45) (my emphasis).

One image, in particular, numbered 27 in the Oficina Alianza and Port of Iquique 1899 album, illustrates Jösch’s case (Figure 2). Entitled, a ‘Group of Desripiodores', it is the set piece of an industrial photographic series, a collective portrait of labouring men: sturdy, strong, muscular, some bare-chested, partially dressed for work, which has just momentarily halted. A row of nitrate miners, shovels in hand, face the photographer and his camera. Their stance, as they waited in the midst of a working day in 1899 on the scaffolding surrounding Shanks tanks for the shutter to fall, 'foreshadows' the gestures of strikers killed in lquique in 1907. Their images, quite out of chronological sequence or even 'against the grain' of history (Benjamin, 2003: 392) evoke the memory of Escuela Santa María massacre (Frazier, 2007). On 15 
December 1907, a general strike of six thousand nitrate workers rallied in lquique, calling for an end to payment in fichas for consumer goods recently inflated in value by fifty per cent and a stable peso value of eighteen pence; they also demanded safer working conditions in the oficinas, an end to corrupt contractors and more public schools. They were joined by railway workers, cart-drivers, artisans and more nitrate miners until fifteen thousand strikers controlled the city, organising from the school. Three days later, government troops arrived with a presidential message that the striker's demands would be met but only if they returned to their oficinas. The strikers refused to leave; Escuela Santa María was surrounded. Micheal Monteón relates that: 'Laborers greeted the soldiers' arrival with hoots; some ripped open their shifts and dared the troops to fire' (Monteón, 1982: 105). Some stood bare-chested; three thousand six hundred were killed, machine gunned, shot, charged by cavalry.

'A Group of Desripiodores', as all photography, loosens time from history. Time as light is fixed upon a plane surface allows a moment to be seen out of a progressive sequence of history: a glimpse, even a grasp, of the past, present and future is seen in its revolutionary disorder. The image of the row of bare-chested nitrate workers is most often reproduced, an image that 'flashes up' (Benjamin, 2003: 390 ) in simultaneous recognition of both the oppression and resistance of Latin American workers, but others of the hundred or so less notable photographs in the album also puncture linear passage of time. The 'architectural structures of the nitrate plants' are subject and setting of many of its images. Photographed full of industrial activity, products and productivity, yet for Jösch, their future as places of 'segregation' can still be seen. The materials of single story blocks of 'The General View of Workmen's Houses', concrete and corrugated iron, are those that comprise the prison cells of Chacabuco, inhabited by the political prisoners of General Pinochet's dictatorship (Figures 13 and 16). When the wide roofed sheds, also clad in corrugated iron, which once stored bags of nitrate awaiting export lay empty at the most northerly port of Pisagua, the isolation lent itself to imprisonment and execution. 
Members of the Popular Unity government in lquique and their relatives were rounded up in the first months of the 1973 coup then transported to the port's prison. The visual and material correspondence of late nineteenth century photographs of nitrate oficinas and their abandoned forms in late twentieth century attest, or at least appear to attest, to an historical correspondence between one moment of the capitalisation of the Chilean landscape in 1890s and another in 1970s. Thus, Andrea Jösch interprets the images of nitrate as Benjaminian allegories; these modern views 'become ruins'. Ruins are allegories made material. 'Allegories are, in the realm of thoughts,' wrote Walter Benjamin, 'what ruins are in the realm of things' (Benjamin, 2003:)

A ruin is a collapsed structure, a fallen edifice. Ruins display decay: a slipping, breaking, crumbling, sliding down, a return to earth. A building decomposes into the materials from which it was made; a human endeavour goes back to nature. Albeit fragile, the ruin has outlasted those who built or dwelt within it. Its eroded structures evoke its entire construction and its inhabitants as well as simply show its current state: it represents what was and what is left. The ruin is an allegory of existence, of life and time passing, of being there and being gone, or, if you can forgive the overused academic shorthand, presence and absence. Always falling but not quite fallen, ruins are never entirely gone. They present a slow drama of loss. Indeed, ruins are about loss rather than absence. Loss has a material form; it is visible and tangible in falling, fragmenting forms; looking at the ruin or walking in them is to track back and forth between a past existence and a present moment. Thus it is possible to see, and perhaps feel, historical change in a ruin; it is not read as a narrative that opens and closes in carefully crafted prose of a history book. Instead, the past just appears in the present. Ruins also have a future aspect. Brian Dillon argues that the ruin is both a 'portal into the past' that 'casts us forward in time'. He states 'it predicts a future in which our present will slump into similar disrepair' (Dillon, 2011: 11). Such an uncanny condition is explicable because the 
moment and form of decay, loss made material, provides both retrospective and prospective views of life. The past can be found in the ruin and the future foretold because, I would suggest, historical change and the passing of time seem present in material form: material transformation as time and 'irresistible decay' as history (Benjamin, 2003: Roth, 1997).

Jösch, staring in the same direction as Benjamin's angel of history (Benjamin, 2003: 392) is saying something different. A Chilean future is not projected from the ruins of the Atacama Desert; these ruins were already there in photography of nitrate mining. From the rows upon rows of boilers providing power to the oficinas only a few are left, the rubble from fallen buildings mixed with the last cinders of coal (Figures 17 and 18). Of the long wooden piers that carried carts of nitrate to be tipped onto drying floors only an incomplete scaffold remain (Figures 8 and 19). Railway tracks are now no more than the lines on the surface of the desert; other uses have been found for the rusty railway girders (Figure 20). And, a handle of a shovel once held by a ripio worker is discarded on a slag heap (Figure 21). The ruins of nitrate mining lie within the industrial structures of nitrate photographs, in images that are both spatial analogies and historical allegories.

The industrial structures of mining will always be abandoned. Dereliction cannot be avoided. When the mined material runs low, is too costly to extract or is no longer considered of value, the architecture of mining begins to empty of activity and soon stands as a monument of disuse. The ruins of the future are ever present. Thus character of the former oficinas of Atacama is shared with the material forms of all extractive industries. But they also are a specific historical formation; they are the industrial colonies of monopoly capitalism.

\section{Walking in Ruins}

Once the driver of that fast moving car arrives in Alianza and turns off the engine, when he or she and the passengers twist around in their seats, slide their legs out, 
step out of the car onto the desert, the view of the oficina is exceeded. Fallen walls give way to further fallen walls in irregular unfinished patterns; sunken lines of railways loop nowhere; large ridged dusty basins show nothing within; vertical weathered wooden shafts rise purposelessly from the ground; oxidised orange metal posts jut out at odd angles; shallow foundations of cellular housing are incomplete, tiled floors curl at the edges. The landscape of the disused mine presents so much detail on so many different surfaces that it cannot be arranged into a view. The ruins are experienced by walking. The sensations of stepping on of the remains of nitrate mining are unexpected, out of the ordinary. The surface is uneven and unstable. The driver and passenger, perhaps tourists or photographers, looters or collectors, historians or former inhabitants, look ahead, around and down, down, around and ahead, considering where to put their feet so constantly switching direction, if only slightly. Tim Edensor has described motion of a body in the space of a ruin:

Instead of moving towards objects and objectives, bodies tend to move arbitrarily in ruins. With the demolition or guided pathways, and social and physical barriers between spaces, as walls and doors collapse, large ruins evolve into a labyrinthine structure which permit the making of a multitude of paths, in contradistinction to the largely linear routes through space determined by processes of production. Thus movement through a ruin is determined by whim or contingency in an improvisational path-making, according to what catches the eye or looks as if it might promise surprises or appears pleasurably negotiable. In the same way that there are no social barriers to movement across space, there are no temporal restrictions that determine how long one should stay in any location, no curbs on loitering or lingering, and no conventions that prevent slow movement or stillness, fostering a freedom over spatial temporalities that can contrast with the fast world outside with its purposive directedness (Edensor, 2005: 87).

Edensor's writing is shaped, and sensitively so, by his experience of walking in the ruins of late twentieth century Britain and the conditions of their decay. '[T]he body is apt to be buffeted by wind and rain, by gusts thick with dust, and atmospheres are often heavy with the presence of damp', he writes. The ruins of the Atacama, also industrial, are of a different order. No pouring or seeping water has altered solid material states to 'provoke sensations of matter crumbling underfoot' (Edensor, 2005: 91). In the driest place on earth, things are broken but brittle. If stepped on, they 
snap. However, Edensor's account of the 'whim or contingency in an improvisational path-making' describes both damp and dry spaces of the ruin (Edensor, 2005: 87). The movement of the arrivals from the Pan Americana within the former nitrate oficina is hesitant, unhurried and halting. Their switching of patterns of motion are an effect of distraction caused by the harvest of broken industrial things that rise from the rubble: broken glass, lampshades made from food tins, shoes mended with industrial components, chipped enamel pots, patched trousers, panels of corrugated iron.

Disused industrial sites, dispersed amongst the different climates of the globe, are all places shaped by the regular routines and rhythms of industry, which then stopped, always abruptly. The slow switching circling or 'improvisational pathmaking' is a kind critical diversion from the 'purposive directedness' of the busy, productive world (Edensor, 2005, 87). For Edensor, walking in ruins is a form of 'freedom' from the industrial order of space and time but it can only occur in devalued domains, in places that are no longer of value because they do not generate it. When materials once mined or made at sites of industrial production are not required for exchange in global markets, neither is their space. 'Uneven geographical development' takes its toll (Harvey, 2006). Industrial dereliction persists in the periphery: the satellites of metropolitan economies (Gunder Frank,1971) are not subject to constant re-development of its centrally located sites. Indeed, nitrate mines have been ruins for longer than they were in operation. Nevertheless, industrial ruins of Britain and Chile share a materiality, not least because the entire industrial system of nitrate mining was an import from one to the other.

To walk on ruins is to step across the debris of an unequal global trade. Amongst the many broken things are some made by hand using the materials of imported supplies, food tins turned into lampshades or mugs. These altered and now discarded forms had saved a little extra exploitation. These fragments are the very last of nitrate mining: its waste matter and concluding document. They are the 
rejected remains, the leftovers of historians and collectors who have archived texts, reproduced them in publications and removed complete objects to museums or heritage sites.

Two former nitrate sites have been intentionally preserved: Humberstone and Santa Laura Saltpeter Works is a World Heritage Site inscribed by UNESCO in 2005 and Oficina Chacabuco, a Chilean national property managed by the Minesterio de Bienes Nacionales since 1990. Chacabuco's status as heritage is more unstable than that of Humberstone: it was declared a national historic monument by President Salvador Allende's government in 1971 then reoccupied as a detention centre in 1973 following the General Pinochet's coup (Vichas, 2011: 249). The two sites present different nitrate histories through different building types: the factory structures of Humberstone and Santa Laura contain an account of the industrial achievements of nitrate processing; Chacabuco holds traces of the lives of nitrate miners and Pinochet's political prisoners. Nevertheless, there are some structural similarities. Entrance gates, ticket booths and information panels announce a place of heritage separate from the space of the desert. Artefacts, including machinery, tools and utensils have been collected and arranged in ways typical of the heritage sector attempts to explain history and exert some control over the past. Labelled objects in vitrines and photographic reprints have been installed on the first floor of Chacabaco's theatre. More extensive exhibitions and period room settings are found throughout Humberstone. Yet, deterioration has not been entirely halted at either site nor all artefacts corralled into demarcated displays. The buildings of both sites, the factory plant or workers' housing, which comprise their heritage, are in various stages of dereliction: in some all walls reach the gentle pitched roof of corrugated iron to form part of a patchwork of panels, their oxidisation producing a terracotta tonal range; others are partial structures. The architecture of both sites is fragile. Indeed, 'fragile', is the term used by UNESCO to describe the condition of Humberstone and the reason why it was listed as 'in Danger' in the same year it was 
accorded World Heritage status. At the edges of each site, debris resurfaces and fragments of working life of the oficina can be found (Figure 22). However, the visitor who wanders away from the routes and rooms defined as heritage must leave through them. Their organisation of objects appears to allay ruination and the sensation of abandonment most acutely felt in the ruin preserved only by the desert environment. Routes permitted by payment and directed by the script of signs, panels and labels do not allow the freedom of ruined space beyond the market for they have been, at least in part, returned to its exchange and order.

The attempts to manage the erosion of nitrate oficina at Humberstone and Chacabuco are exceptions. Before its collapse in the early twentieth century, the industry was extensive, employing over 200,000 workers in the regions of Antofagasta and Tarapacá (Monteón, 1979: 70). Thus, the ruins of nitrate mining lie everywhere across the Atacama. Indeed, their preserved decay is the most important archaeological record of nitrate mining. Their concentrations of broken materials mark the location of nitrate oficinas and the extent of industrial colonialsation.

\section{Last words}

Towards the very end of the nineteenth century, the industrial structures that appear in the Oficina Alianza and Port of Iquique 1899 album of photographs are installed: the lines of railway track, the bolted metal sheets of the crushers, the long wooden piers that supported Shanks crystallising tanks, the corrugated iron panels, which covered every industrial workshop and nitrate worker's house. Alianza is occupied and becomes, to borrow Tim Edensor's words, part of the 'fast world' with 'its purposive directedness' (Edensor, 2005: 87). Movement, the subject of so many of the album's photographs that show the dust clouds of material transformation or the loading of bags upon bags of stuff, documents industrial activity and depicts an industrial space: the Atacama Desert is incorporated into the domain of monopoly capital. Exploding, prising, crushing, diluting, drying, shovelling, hauling nitrate is 
drawn towards its export: the movement of material is that of global economic exchange.

The empty spaces of the ruin announce that such exchange relationships are over. Disused industrial structures preserved in their fragmentary form an outline of long ceased industrial activity. At Alianza, as at all ruins of the Atacama, absence is visible and material. The denuded buildings, the vertical shafts without horizontal platforms, the shards of corrugated iron, the patches of broken glass and the lines in the sand where railway tracks once ran are documents of the end of the nitrate industry. Such a loss is also experienced as stillness interrupted by the meandering movements of visitors. There is little or no movement in places withdrawn from an industrial economy until the tourist or photographer, looter or collector, historian or former inhabitant re-enters, stepping wherever they wish, twisting and turning, improvising their own route. Industrial loss is experienced as a strange spatial freedom. Industrial ruins are, as Tim Edensor argues, marginal spaces in which time can be wasted in unregulated movement. Indeed, to walk in the ruins of the Oficina Alianza is to stumble freely over mounds of waste that may appear as layers of loss Waste and loss began before nitrate mining was abandoned, that is, by industrial production rather than its end. Its industrial structures, which hosted the stages of industrial production so carefully composed in its photographic album, were erected, as Andrea Jösch observed, to be ruins. Material loss was produced through nitrate mining even as its was operating at a profit; extracted materials and exchange values would never be returned to the desert except as waste. The slag heaps, their forms created by tipping layer upon layer of ripio now appear as natural desert formations, flat mountains seen from the Pan Americana.

\section{References}

Benjamin, W. 2003. The Origin of German Tragic Drama. London: Verso. 
Benjamin, W. 2003. On the Concept of History. In Howard Eiland and Michael W, Jennings, Walter Benjamin: Selected Writings Volume 4, 1938-1940, Massachusetts: Harvard University Press.

Blakemore, H. 1974. British Nitrates and Chilean Politics, 1886-1896: Balmaceda and North London: University of London/Althone Press.

Brown, J. R. 1958. The Chilean Nitrate Railways Controversy. The Hispanic American Historical Review, Vol. 38, No.4 (Nov), pp.465-481.

Brown, J.R. 1963. Nitrate Crises, Combinations, and the Chilean Government in the Nitrate Age. The Hispanic American Historical Review, Vol.43, No. 2 (May), pp. 230246.

Clark, B. and Foster, J.B. 2009. Ecological Imperialism and the Global Metabolic Rift: Unequal Exchange and the Guano/Nitrates Trade. International Journal of Comparative Sociology, Vol 50 (3-4), pp. 311- 334.

Dillon, B. 2011. Introduction: A Short History of Decay. In Brian Dillon (ed), Ruins. Whitechapel Gallery, Cambridge Massachusetts and London: MIT Press, pp.10-19. Edensor, T. Industrial Ruins: Space, Aethetics and Materiality. Oxford: Berg, 2005. Edmundson, W. 2011. The Nitrate King: A Biography of "Colonel" John Thomas North. New York: Palgrave Macmillan.

Espinosa, I. n.d.Catalogo de las Fichas, Vales et Billetes Salitreros de Chile, Peru y Bolivia, Santiago: Ismael Espinosa.

Frazier, L.J. 2007.Salt in the Sand: Memory, Violence and the Nation-State in Chile, 1890 to the Present, Durham: Duke University Press.

Gunder Frank, A. 1971. Capitalism and Underdevelopment in Latin America [1969] Middlesex: Penguin Books.

Haber, L.F. 1958. The Chemical Industry during the Nineteenth Century. Oxford: Oxford University Press.

Harvey, D. Spaces of Global Capitalism: Towards a Theory of Uneven Geographical Development, London and New York: Verso, 2006. 
Jösch, A. 2014. The Photography of an Inhospitable Territory. In Ribas, X., Nitrate. Barcelona: MACBA (Museu D’Art Contemporani de Barcelona), pp. 43-46.

Miller, R. and Greenhill, R. 2006. Fertilizer Commodity Chains: Guana and Nitrate 1840-1930. In Steven Topik, Carlos Marichal and Zephyr Frank (eds), From Silver to Cocaine: Latin American Commodity Chains and the Building of the World Economy, Durham: Duke University Press.

Monteón, M. 1975. The British in the Atacama Desert: the Cultural Bases of Economic Imperialism. The Journal of Economic History, Vol. 35 No. 1, March, pp. 117-133.

Monteón, M. 1979. The Enganche in the Chilean Nitrate Sector, 1880-1930.Latin American Perspectives, Vol. 6. No.3, Summer, 66-79.

Monteón, M. 1982. Chile in the Nitrate Era: the Evolution of Economic Dependence, 1880-1930. Wisconsin: The University of Wisconsin Press.

Roth, M. S., Lyons, C. and Merewether, C. 1997. Irresistible Decay: Ruins Reclaimed. Los Angeles: Getty Institute.

Sekula, A. 1986. Reading an Archive: Photography between Labour and Capital. In Patricia Holland (et al eds). Photography/Politics: Two, London: Comedia Publishing Group.

Strangleman, T. 2013. "Smokestack Nostalgia”, 'Ruin Porn” or Working-Class Obitruary: the Role and Meaning of Delndustrial Representation. International Labor and Working-Class History, No.84 Fall, pp.23-37.

Vilches, F. 2011. From nitrate town to internment camp: the cultural biography of Chacabuco, northern Chile. Journal of Material Culture, 16 (3), pp. 241-263. 